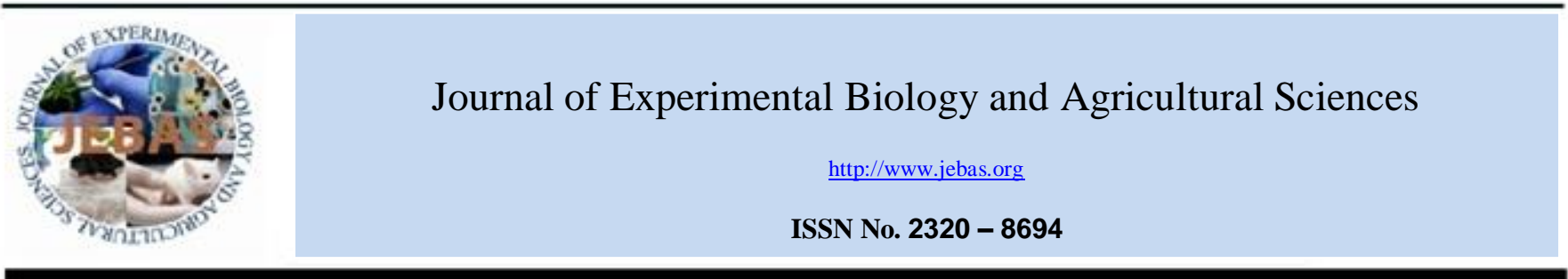

\title{
LEVERAGING TRADITIONAL CROPS FOR FOOD AND FEED: A CASE OF HULLESS BARLEY (HORDEUM VULGARE) LANDRACES IN ETHIOPIA
}

\author{
Jane Wamatu ${ }^{1 *}$, Ashraf Alkhtib ${ }^{2}$, Mekides Woldegiorgis Gardi ${ }^{3}$ \\ ${ }^{1}$ International Center for Agricultural Research in Dry Areas, Addis Ababa, Ethiopia, P.O Box 5689, Addis Ababa. \\ ${ }^{2}$ Nottingham Trent University, School of Animal, Rural and Environmental Sciences, Brackenhurst Campus, Southwell, Nottinghamshire, the UK. \\ ${ }^{3}$ Addis Ababa University College of Natural Science, Addis Ababa, Ethiopia.
}

Received - December 09, 2018; Revision - January 28, 2019; Accepted - January 31, 2019

Available Online - February 5, 2019

DOI: http://dx.doi.org/10.18006/2019.7(1).42.50

KEYWORDS
Food-feed
Genotypic variation
Landraces
Hulless barley
Nutritive value
Straw

\begin{abstract}
This study explored food-feed traits in genotypes of 25 indigenous Ethiopian landraces, 13 landraces introduced into Ethiopia and 5 local checks of hulless barley (Hordeum vulgare). The genotypes were evaluated for straw fodder quality traits and the traits were related to grain yield and straw yield. The genotypes were grown in Ethiopia during the 2016 cropping season using augmented design consisting of 5 complete blocks. Results of the study showed high genotypic variability in grain yield (5.1 t/ha), straw yield (7.03 t/ha) and straw content of crude protein (CP: $29.1 \mathrm{~g} / \mathrm{kg}$ ), neutral detergent fiber (NDF: $77 \mathrm{~g} / \mathrm{kg}$ ), acid detergent fiber (ADF: $41 \mathrm{~g} / \mathrm{kg}$ ), acid detergent lignin (ADL: $22.7 \mathrm{~g} / \mathrm{kg}$ ) and invitro organic matter digestibility (IVOMD: $72 \mathrm{~g} / \mathrm{kg}$ ). Further, cluster analysis determined 6 genotypes i.e. 243231, 241790, 219177, 243235, 241787, 241789 among Ethiopian landraces that showed food-feed traits with an average of $3.44 \mathrm{t} / \mathrm{ha}$ of grain, $5.64 \mathrm{t} / \mathrm{ha}$ of straw and $55.9 \mathrm{~g} / \mathrm{kg}$ of CP. The correlation between grain yield with straw yield and nutritive value parameters was insignificant. Principle component analysis determined that either CP, NDF or IVOMD can express the nutritive value of hulless barley straw. The study highlights the natural genotypic variation in grain yield and straw traits in hulless barley that can be exploited using appropriate breeding methods to develop varieties with a combination of food traits for human food and feed traits for livestock feed. These varieties would be particularly beneficial for mixed crop-livestock systems that are predominant in developing countries.
\end{abstract}

* Corresponding author

E-mail: J.Wamatu@cgiar.org (Jane Wamatu)

Peer review under responsibility of Journal of Experimental Biology and Agricultural Sciences.

Production and Hosting by Horizon Publisher India [HPI] (http://www.horizonpublisherindia.in/).

All rights reserved.
All the article published by Journal of Experimental Biology and Agricultural Sciences is licensed under a Creative Commons Attribution-NonCommercial 4.0 International License Based on a work at www.jebas.org.

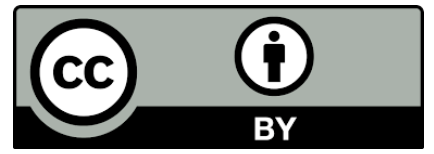




\section{Introduction}

Barley (Hordeum vulgare L.) is one of the earliest domesticated crops (Mamo et al., 2014).) and the fourth most important cereal in terms worldwide production (FAO, 2016). More than half of land area under barley crop is in developing countries (Grando \& Macpherson, 2005). In Ethiopia, barley is among the oldest cultivated crops and has been grown for at least 5,000 years, in a wide range of agro-ecologies (Mamo et al., 2014). It has high economic and social importance as human food, malt for brewing and animal feed (Kaso \& Guben, 2015). Most barley varieties are hulled, however, hulless barley (hulless barley) is gaining preference due to the ease with which it can be processed, prepared and presented for food (Zohary \& Hopf, 2000). Barley occupies about 959,000 hectares of land with total production of 2,025,000 tones (CSA, 2016). In the predominantly mixed croplivestock systems of Ethiopia, the potential contribution of barley straw to the feed supply of livestock is significant. A grain yield of $3 \mathrm{t} /$ ha of barley is associated with approximately $4 \mathrm{t}$ of straw (Cooper et al., 2001) which could feed a $300 \mathrm{~kg}$ cow for 800 days (calculation based on Kearl, 1982). However, barley straw, with an inherently low nutritive value (38 g/kg CP, $6 \mathrm{MJ} / \mathrm{kg} \mathrm{ME}$ and 27 $\mathrm{g} / \mathrm{kg} 0.75$ dry matter intake) (Heuzé et al., 2016), cannot cover maintenance requirements of the cow over that period (Goodchild, 1997). The trend that straws represent an increasingly important part of total crop value has been reported (Kelley et al., 1991). However, new improved varieties and cultivation methods have been reported to lead to a decrease in straw yields (Austin et al., 1980; Riggs et al.,1981). Rejection of improved varieties because of poor straw traits has been reported in barley (Capper et al., 1986; Capper et al., 1988). In India, wheat farmers requested wheat breeders to consider straw yield in wheat improvement programs (Schiere et al., 2004). Traxler \& Byerlee (1993) reported that the economic value of straw is an important criterion in the adoption of new cereal varieties by small holder mixed crop-livestock farmers. Accordingly, the development of high grain yielding varieties of food and malt barley by the International Center for Agricultural Research in Dry Areas (ICARDA), which holds the world mandate for barley, needs to consider straw traits. ICARDA has reported on the possibility of breeding for dual purpose barley with high forage yield as well as high grain yield for the Mediterranean region where green stage barley grazing is practiced. Studies to simultaneously boost grain yield and straw nutritive value traits of cereal and grain legume crops are ongoing at ICARDA. Several studies have reported on the possibility of improving grain yield alongside straw traits of lentil (Alkhtib et al., 2017), chickpea (Wamatu et al., 2017), maize (Ertiro et al., 2013) and pearl millet (Blümmel et al., 2010). A focus on dual purpose hulless barley for high grain yield, high straw yield and high nutritive value would be particularly relevant for regions in Asia and Sub-Saharan Africa where straw feeding to livestock is commonly practiced. Landraces are still the backbone of agricultural systems in many developing countries as they are characterized by high genetic heterogeneity and good adaptation to local environmental conditions (Ceccarelli \& Grando, 1996). We hypothesize that there is a possibility to find hulless barley landraces which combine superior food and feed traits. The Ethiopian gene bank collection on hulless barley germplasm consists of landraces indigenous to Ethiopia, henceforth referred to as ETH landraces, and those introduced from other regions, henceforth referred to as introduced landraces. This study aims to characterize for grain yield and straw traits and to identify the food-feed relations in Ethiopian landraces of hulless barley for use in future breeding work on dual-purpose barley.

\section{Materials \&Methods}

\subsection{Experimental material}

A total of 43 hulless barley germplasms which included $25 \mathrm{ETH}$ landraces obtained from the Ethiopian Biodiversity Institute (initially collected from 11 administrative zones), 13 introduced landraces originally obtained from the gene bank of ICARDA and 5 local checks obtained from Holetta Agricultural Research Center (HARC), Ethiopia were obtained for the study (Table 1).

\subsection{Experimental site}

Trials were conducted at $\mathrm{HARC}\left(9^{\circ} 3^{\prime} \mathrm{N}, 38^{\circ} 30^{\prime} \mathrm{E}\right.$, altitude 2400 m.a.s.l), during the main cropping season of 2016 (July December) under rainfed conditions. Mean maximum and minimum temperatures during the study were 22.1 and $6.2^{\circ} \mathrm{C}$ respectively. The experiment was laid out in an augmented randomized complete block design (Federer \& Ragavarao, 1975) consisting of 5 blocks in which ETH landraces and introduced landraces were planted in un-replicated plots and 5 local checks genotypes were replicated 5 times to estimate experimental error variance. Plot size was $2.5 \mathrm{~m}$ length and $0.4 \mathrm{~m}$ between rows. Fertilizer was applied at a rate of 50/100 kg/ha, urea/DAP. Trial were managed as per recommended practice for barley cultivation. At physiological maturity, plots were manually harvested from 2 areas $(1.6 \mathrm{~m} 2)$ laid over 2 middle rows of each plot. After sundrying and threshing of biomass, representative samples from each plot were analysed for chemical composition and digestibility.

\subsection{Straw quality analysis}

Oven-dried $\left(100^{\circ} \mathrm{C} ; 24 \mathrm{~h}\right)$ samples were ground, sieved through a $1 \mathrm{~mm}$ mesh and analysed using a combination of conventional laboratory analysis and Near Infrared Spectroscopy (NIRS; Foss 
Table 1 Description of germplasm used in the current study

\begin{tabular}{|c|c|c|c|c|}
\hline Accession name & Origin/Zones & Region & Genetic status & Altitude (m.a.s.l) \\
\hline HB-42 & Holetta & Oromia & Improved & NA \\
\hline Ardu & Holetta & Oromia & Improved & NA \\
\hline Shege & Holetta & Oromia & Improved & NA \\
\hline HB1703 & Holetta & Oromia & Improved & NA \\
\hline Balami & Holetta & Oromia & Improved & NA \\
\hline 244772 & Kembata & SNNP & ETH landrace & $2500-3000$ \\
\hline 64164 & North Omo & SNNP & ETH landrace & $2500-3000$ \\
\hline 243606 & North Gonder & Amhara & ETH landrace & $2500-3000$ \\
\hline 238663 & North Shewa & Oromia & ETH landrace & $2500-3000$ \\
\hline 243231 & North Shewa & Oromia & ETH landrace & $2500-3000$ \\
\hline 219177 & East Harerge & Oromia & ETH landrace & $2500-3000$ \\
\hline 64080 & North Gonder & Amhara & ETH landrace & $2500-3000$ \\
\hline 241790 & South Gonder & Amhara & ETH landrace & $2500-3000$ \\
\hline 219763 & South Gonder & Amhara & ETH landrace & $2500-3000$ \\
\hline 243235 & North Shewa & Amhara & ETH landrace & $2500-3000$ \\
\hline 244904 & East Wellega & Oromia & ETH landrace & $2500-3000$ \\
\hline 235540 & Gurage & SNNP & ETH landrace & $>3000$ \\
\hline 64118 & Arsi & Oromia & ETH landrace & $>3000$ \\
\hline 4752 & North Shewa & Oromia & ETH landrace & $>3000$ \\
\hline 243171 & South Gonder & Amhara & ETH landrace & $>3000$ \\
\hline 243576 & North Wello & Amhara & ETH landrace & $>3000$ \\
\hline 238750 & South Wello & Amhara & ETH landrace & $>3000$ \\
\hline 64068 & South Gonder & Amhara & ETH landrace & $>3000$ \\
\hline 241788 & South Gonder & Amhara & ETH landrace & $>3000$ \\
\hline 241787 & North Gonder & Amhara & ETH landrace & $>3000$ \\
\hline 241789 & North Gonder & Amhara & ETH landrace & $>3000$ \\
\hline 215223 & North Wello & Amhara & ETH landrace & $>3000$ \\
\hline 215224 & North Wello & Amhara & ETH landrace & $>3000$ \\
\hline 215689 & South Wello & Amhara & ETH landrace & $>3000$ \\
\hline 215204 & West Shewa & Oromia & ETH landrace & NA \\
\hline ICARDA 1 & ICARDA & NA & Introduced landrace & NA \\
\hline ICARDA 2 & ICARDA & NA & Introduced landrace & NA \\
\hline ICARDA 3 & ICARDA & NA & Introduced landrace & NA \\
\hline ICARDA 4 & ICARDA & NA & Introduced landrace & NA \\
\hline ICARDA 5 & ICARDA & NA & Introduced landrace & NA \\
\hline ICARDA 6 & ICARDA & NA & Introduced landrace & NA \\
\hline ICARDA 7 & ICARDA & NA & Introduced landrace & NA \\
\hline ICARDA 8 & ICARDA & NA & Introduced landrace & NA \\
\hline ICARDA 9 & ICARDA & NA & Introduced landrace & NA \\
\hline ICARDA 10 & ICARDA & NA & Introduced landrace & NA \\
\hline ICARDA 11 & ICARDA & NA & Introduced landrace & NA \\
\hline ICARDA 12 & ICARDA & NA & Introduced landrace & NA \\
\hline ICARDA 13 & ICARDA & NA & Introduced landrace & NA \\
\hline
\end{tabular}

ETH: Ethiopian, ICARDA: International Center for Agricultural Research in Dry Areas, NA: not available 
Forage Analyser 5000 with software Package WinISI II in 1108-2492 $\mathrm{nm}$ spectra range). A basal NIRS calibration was developed and validated by wet chemistry analyses of $20 \%$ representative samples. For conventional analyses, dry matter (DM) and crude protein (CP) were determined as per procedures of AOAC (2005). Crude protein was calculated from nitrogen by multiplication with the factor of 6.25. Cell wall fractions namely neutral detergent fiber (NDF), acid detergent fiber (ADF) and lignin were determined as described by Van Soest et al. (1991). In vitro organic matter digestibility was measured in rumen microbial inoculum using in vitro gas production technique (Menke \& Steingass, 1988) and calculated using the equation below suitable for roughages as described by Menke et al. (1979).

$\operatorname{IVOMD}(\mathrm{g} / \mathrm{kg})=14.88+0.889 * \mathrm{GP}+0.45 * \mathrm{CP}+0.0651 * \mathrm{XA}$

Where GP: 24 h net gas production (ml/200 mg); CP: Crude protein (g/kg DM); XA: Ash content (g/kg DM).

\subsection{Statistical analysis}

Data was analysed using SAS version 12.1 Software (SAS, 2012). A mixed model was used for analysis of variance as follows

$Y_{i j}=M+A_{i}+B_{j}+E_{i j}$

Where: Yij is response variable; $M$ is general mean, $A i$ is the fixed effect of the ith standard checks and random effect of genotypes, Bj is the random effect of jth block and Eij is the random error. The relationship between grain yield and straw traits was determined using Pearson correlation.
To quantify the contribution of major determinants (CP, NDF, IVOMD) of nutritive value of straw, principal component analysis (PCA) was carried out using standardized data.The signs and magnitudes of the eigenvectors were examined for relevance. Relevance was based on the facts that NDF is negatively correlated to DM intake (Horrocks \& Vallentine, 1999) and IVOMD is positively correlated to metabolizable energy (ME). Results from the PCA determined which nutritive parameters would be included in cluster analysis.Cluster analysis was used to classify the genotypes into homogenous groups/clusters depending on similarity in grain yield, straw yield and straw nutritive value parameters. Values of pseudo F statistics and Hotellin's pseudo T2 statistics were used to identify the optimum number of clusters. Cluster analyses was carried out using standardized data. Standardized data was used in principle component analysis and cluster analysis to unify units of measurement.

\section{Results}

\subsection{Grain yield and straw yield}

Table 2 and 3 present results of descriptive analyses and analysis of variance of grain and straw traits for hulless barley landraces. There were significant $(\mathrm{P}<0.05)$ variations in grain yield among local checks, ETH landraces, but not among introduced landraces. Combined means of grain yield of ETH landraces were significantly higher than local checks and introduced landraces. Grain yield ranges were $0.473-5.49$ t/ha among ETH landraces, $0.184-1.68 \mathrm{t} / \mathrm{ha}$ among introduced landraces and $1.16-5.63 \mathrm{t} / \mathrm{ha}$ among local checks. Considering all genotypes in this study, the magnitude of range in grain yield was 4.92 t/ha. The minimum yielding genotype was found in ETH landraces while the

Table 2 Mean squares of grain yield and straw traits of hulless barley genotypes

\begin{tabular}{|c|c|c|c|c|c|c|}
\hline \multirow[b]{2}{*}{ Traits } & \multirow[b]{2}{*}{$\begin{array}{l}\text { Among } \\
\text { checks }\end{array}$} & \multicolumn{4}{|c|}{ Source of variance } & \multirow[b]{2}{*}{$\begin{array}{l}\text { Introduced } \\
\text { landraces vs. } \\
\text { checks }\end{array}$} \\
\hline & & $\begin{array}{l}\text { Among } \\
\text { ETH } \\
\text { landraces }\end{array}$ & $\begin{array}{l}\text { Among } \\
\text { introduced } \\
\text { landraces }\end{array}$ & $\begin{array}{l}\text { ETH Landraces } \\
\text { vs. checks }\end{array}$ & $\begin{array}{l}\text { ETH Landraces vs. } \\
\text { introduced landraces }\end{array}$ & \\
\hline Grain yield (t/ha) & 5.47 & 2.36 & $0.22 \dagger$ & 2.95 & 27.6 & 23.6 \\
\hline Straw yield (t/ha) & 4.9 & 4.94 & $1.5 \dagger$ & $2.01 \dagger$ & 27.1 & 21.3 \\
\hline $\mathrm{CP}$ & 102 & 63.8 & 50.3 & 1804 & 259 & 382 \\
\hline NDF & 4118 & 1096 & 1356 & $1253 \dagger$ & 5638 & 5971 \\
\hline $\mathrm{ADF}$ & 2488 & 1230 & 1041 & 5299 & 7515 & 12597 \\
\hline $\mathrm{ADL}$ & 157 & 86.5 & 78.5 & 686 & 520 & 1197 \\
\hline IVOMD & 2880 & $442 \dagger$ & 585 & 9238 & $209 \dagger$ & 3523 \\
\hline
\end{tabular}

$\dagger: \mathrm{P}>0.05$ otherwise $\mathrm{P} \leq 0.05, \mathrm{CP}$ : crude protein $(\mathrm{g} / \mathrm{kg} \mathrm{DM})$, NDF: neutral detergent fiber (g/kg DM), ADF: acid detergent fiber ( $\mathrm{g} / \mathrm{kg} \mathrm{DM})$,

ADL: acid detergent lignin (g/kg DM), IVOMD: in vitro organic matter digestibility (g/kg), ETH: Ethiopian. 
Table 3 Descriptive statistics for grain yield and straw traits of hulless barley genotypes

\begin{tabular}{|ccc|cccccccc|}
\hline \multirow{2}{*}{ Variable } & \multicolumn{3}{c}{ ETH landraces } & \multicolumn{3}{c}{ Introduced landraces } & \multicolumn{3}{c|}{ Local checks } \\
\cline { 2 - 10 } & Mean & Min & Max & Mean & Min & Max & Mean & Min & Max \\
\hline Grain yield (t/ha) & 3.11 & 0.473 & 5.49 & 1.01 & 0.184 & 1.68 & 2.84 & 1.16 & 5.63 \\
\hline Straw yield (t/ha) & 4.29 & 0.863 & 7.9 & 2.49 & 0.64 & 4.98 & 4.01 & 1.50 & 9.32 \\
\hline CP & 45.3 & 30 & 59 & 39.6 & 25.7 & 50.2 & 32.3 & 24.3 & 45.6 \\
\hline NDF & 815 & 781 & 858 & 780 & 717 & 836 & 813 & 706 & 860 \\
\hline ADF & 576 & 530 & 617 & 538 & 484 & 588 & 583 & 501 & 624 \\
\hline ADL & 84.6 & 74.6 & 97.3 & 74.2 & 56.4 & 89.8 & 88.1 & 72.5 & 107 \\
\hline IVOMD & 440 & 400 & 472 & 439 & 385 & 487 & 414 & 362 & 460 \\
\hline
\end{tabular}

CP: crude protein (g/kg DM), NDF: neutral detergent fiber (g/kg DM), ADF: acid detergent fiber (g/kg DM), ADL:acid detergent lignin (g/kg DM), IVOMD: in vitro organic matter digestibility (g/kg), ETH: Ethiopian.

maximum yielding genotype was found within local checks. Variation in straw yield in ETH landraces and local checks genotypes was significant $(\mathrm{P}<0.05)$. ETH landraces and local checks were not significantly different. Combined mean of straw yield of ETH landraces was higher $(\mathrm{P}<0.05)$ than introduced landraces. Range in straw yield was $0.863-7.9 \mathrm{t} / \mathrm{ha}, 0.64-4.98$ t/ha and 1.5 - $9.32 \mathrm{t} / \mathrm{ha}$ in ETH landraces, introduced landraces and local checks respectively. The minimum and maximum straw yielders were found in introduced landraces and local checks respectively. Considering all genotypes, the difference in yield was $8.46 \mathrm{t} / \mathrm{ha}$.

\subsection{Straw nutritive value}

Table 2 and 3 present results of descriptive analysis and analysis of variance of straw traits. Variation in $\mathrm{CP}$ and cell wall constituents was significant $(\mathrm{P}<0.05)$ among the 3 groups. In vitro organic matter digestibility varied significantly among local checks and introduced landraces but not for ETH landraces. This indicated that $\mathrm{CP}$ and NDF of ETH landraces were significantly higher $(\mathrm{P}<0.05)$ than introduced landraces. The difference between ETH landraces and checks in NDF was insignificant. Means of ADF, ADL and IVOMD of ETH landraces were significantly higher than introduced landraces but less than local checks. The range of CP was $30-59 \mathrm{~g} / \mathrm{kg}, 25.7-50.2 \mathrm{~g} / \mathrm{kg}$ and 24.3 - $45.6 \mathrm{~g} / \mathrm{kg}$ in ETH landraces, introduced landraces and local checks respectively. The range of NDF was $781-858 \mathrm{~g} / \mathrm{kg}, 717$ $836 \mathrm{~g} / \mathrm{kg}$ and $706-860 \mathrm{~g} / \mathrm{kg}$ within landraces, introduced landraces and local checks respectively. The range of ADF was $530-617 \mathrm{~g} / \mathrm{kg}, 484-588 \mathrm{~g} / \mathrm{kg}$ and $501-624 \mathrm{~g} / \mathrm{kg}$ in ETH landraces, introduced landraces and local checks respectively. The range of ADL was $74.6-97.3 \mathrm{~g} / \mathrm{kg}, 56.4-89.8 \mathrm{~g} / \mathrm{kg}$ and $72.5-$ $107 \mathrm{~g} / \mathrm{kg}$ in ETH landraces, introduced landraces and local checks respectively. The range of IVOMD was $400-472 \mathrm{~g} / \mathrm{kg}, 385$ - 487 $\mathrm{g} / \mathrm{kg}$ and $362-460 \mathrm{~g} / \mathrm{kg}$ in ETH landraces, introduced landraces and local checks respectively. Genotypes which had the lowest and the highest $\mathrm{CP}$ were found in local checks and ETH landraces respectively. The lowest and highest genotypes in terms of NDF were found in local checks. The lowest and highest genotypes regarding $\mathrm{ADF}$ and $\mathrm{ADL}$ were found in introduced landraces and local checks respectively. Genotypes with the lowest and highest IVOMD were found in local checks and introduced genotypes respectively. Considering all genotypes, the magnitude of range in $\mathrm{CP}, \mathrm{NDF}, \mathrm{ADF}, \mathrm{ADL}$ and IVOMD was $34.7 \mathrm{~g} / \mathrm{kg}, 154 \mathrm{~g} / \mathrm{kg}, 176$ $\mathrm{g} / \mathrm{kg} 50.6 \mathrm{~g} / \mathrm{kg}$ and $125 \mathrm{~g} / \mathrm{kg}$ respectively.

\subsection{Principal component analysis}

Principle component analysis generated 3 principle components (Table 4). Principle component 1 explained $71.1 \%$, majority of the variability of nutritive value of straw. PC1 best expressed the nutritive value of straw because an examination of eigenvectors showed that CP and IVOMD had positive signs suggesting they would contribute positively to nutritive value of straw while NDF had negative sign suggesting it would contribute negatively to the nutritive value of straw. The magnitude of eigenvectors was almost similar, $0.558,-0.566$ and 0.606 for CP, NDF and IVOMD respectively, which implies that either of the eigenvectors can be used to represent the nutritive value of barley straw. Therefore, $\mathrm{CP}$ was included in cluster analysis because it represents the nutritive value of straw and it is a critical parameter considering that straws of cereals are known to have low CP contents.

\subsection{Cluster analysis based on food-feed traits}

Cluster analysis grouped the 43 genotypes into 5 clusters based on grain yield and straw traits (Table 5). The number of genotypes distributed across each cluster was as follows: 9, 17, 6, 5 and 6 in cluster 1, 2, 3, 4 and 5 respectively. Cluster 1 was dominated by 
Table 4 Principle component analysis of the nutritive parameters of hulless barley straw

\begin{tabular}{|cccc|}
\hline Statistics & PC1 & PC2 & PC3 \\
\hline Eigenvalue & 2.13 & 0.525 & 0.341 \\
\hline Variation explained (\%) & 71.1 & 17.5 & 11.3 \\
\hline Eigenvectors & & & -0.379 \\
\hline CP & 0.558 & 0.738 & 0.475 \\
\hline NDF & -0.566 & 0.672 & 0.793 \\
\hline IVOMD & 0.606 & -0.05 & \\
\hline
\end{tabular}

CP: crude protein, NDF: neutral detergent fibers, IVOMD:in vitro organic matter digestibility.

Table 5 Cluster means of major food and feed traits of hulless barley

\begin{tabular}{|c|c|c|c|c|c|}
\hline & \multicolumn{5}{|c|}{ Cluster } \\
\hline & 1 & 2 & 3 & 4 & 5 \\
\hline Total genotypes (N) & 9 & 17 & 6 & 5 & 6 \\
\hline $\mathrm{N}$ of landraces & 5 & 11 & 2 & 1 & 6 \\
\hline $\mathrm{N}$ of introduced & 3 & 6 & 2 & 2 & 0 \\
\hline $\mathrm{N}$ of local check & 1 & 0 & 2 & 2 & 0 \\
\hline \multicolumn{6}{|l|}{ Food-feed traits } \\
\hline Grain yield (t/ha) & $2.58(80.3)$ & $2.26(56.3)$ & $1.44(85.2)$ & $2.83(58.7)$ & $3.44(44.5)$ \\
\hline Straw yield (t/ha) & $2.53(57.2)$ & $3.88(38.1)$ & $3.38(55.7)$ & $3.36(22.9)$ & $5.64(29.4)$ \\
\hline $\mathrm{CP}(\mathrm{g} / \mathrm{kg})$ & $37.9(2.8)$ & $46.6(5.04)$ & $33.3(4.41)$ & 28.4(7.38) & $55.9(4.13)$ \\
\hline $\mathrm{NDF}(\mathrm{g} / \mathrm{kg})$ & $804(3.2)$ & $790(5.25)$ & $827(0.6)$ & $836(2.13)$ & $792(1.14)$ \\
\hline IVOMD (g/kg) & $438(2.18)$ & $446(4.67)$ & $418(5.11)$ & $411(5.24)$ & $447(2.75)$ \\
\hline
\end{tabular}

CP: Crude protein, Value between parentheses denotes coefficient of variation, N: number of.

Table 6 Correlation coefficients between grain yield and straw traits

\begin{tabular}{|cccc|}
\hline Straw traits & ETH landraces & Introducedlandraces & Local checks \\
\hline Straw yield & $\mathrm{ns}$ & 0.611 & $\mathrm{~ns}$ \\
\hline CP & $\mathrm{ns}$ & $\mathrm{ns}$ & $\mathrm{ns}$ \\
\hline NDF & $\mathrm{ns}$ & $\mathrm{ns}$ & 0.429 \\
\hline ADF & $\mathrm{ns}$ & $\mathrm{ns}$ & 0.426 \\
\hline ADL & $\mathrm{ns}$ & $\mathrm{ns}$ & 0.568 \\
\hline IVOMD & $\mathrm{ns}$ & $\mathrm{ns}$ & -0.641 \\
\hline
\end{tabular}

CP: crude protein (g/kg DM), NDF: neutral detergent fiber (g/kg DM), ADF: acid detergent fiber ( $\mathrm{g} / \mathrm{kg}$ DM), ADL: acid detergent lignin ( $/ \mathrm{kg}$ DM), IVOMD: in vitro organic matter digestibility $(\mathrm{g} / \mathrm{kg})$, ns: $\mathrm{P}>0.05$ otherwise $\mathrm{P} \leq 0.05$.

introduced landraces (88\%). ETH landraces dominated cluster 2 representing $65 \%$ of the total genotypes. Cluster 3 was equally dominated by the three groups of genotypes. Cluster 4 mainly constituted of introduced landraces and local checks (80\%). All genotypes in cluster 5 were ETH landraces. Cluster 5 had the highest grain yield, straw yield, CP, IVOMD compared to other clusters.

\subsection{Correlation between grain yield and straw traits}

ETH landraces, local checks and introduced landraces had different food-feed correlation profiles (Table 6). No correlation between grain yield and straw yield or grain yield and nutritive traits was found in both ET and introduced landraces. Grain yield in introduced genotypes, correlated moderately and positively to 
straw yield while it did not correlate to nutritive value parameters of straw. There was no correlation between grain yield and straw yield and grain yield and CP in local checks. Grain yield correlated positively and moderated to cell wall constituents and negatively and strongly to IVOMD.

\section{Discussion and conclusions}

Wide genetic range in grain yield, straw yield and nutritive value was found among ETH landraces, introduced landraces and local checks. Furthermore, combined data from all genotypes showed wider ranges indicating the possibility to improve both grain yield and straw traits by simple selection. Generic variation in grain yield and straw traits was also observed in maize (Ertiro et al., 2013), in chickpea (Wamatu et al., 2017) and in lentil (Alkhtib et al., 2017; Wamatu et al., 2017). Crude protein content in feeds is important to achieve optimum rumen activity in addition to ensuring adequate dry matter intake of feed. A level of 70-80 g/kg $\mathrm{CP}$ and 100-110 g/kg CP are recommended for non-lactating and lactating cows respectively. The highest level of $\mathrm{CP}$ among the genotypes in the study was $59 \mathrm{~g} / \mathrm{kg}$. However, CP content of crop residues can be improved through agronomic practices, particularly by applying a feasible level of nitrogen fertilization (Blümmel et al. 2007; Mosisa et al. 2007). Dry matter intake of low-quality roughages is closely and negatively associated with NDF content (Horrocks \& Vallentine 1999). Wide genotypic variation in NDF content of barley straw was found in this study, indicating that dry matter intake of barley straw could be improved by exploiting natural variability in straw content of NDF. However, dry matter intake is affected by other factors such as physical and morphological properties of feed and species of livestock. Thus, it is important to test palatability of straws of newly developed hulless barley genotypes before release. Interaction between genotype and location in straw traits has been reported in maize (Ertiro et al., 2013). Thus, more studies are needed to determine genotype-environment interactions in hulless barley. Principle component analysis showed that $\mathrm{CP}, \mathrm{NDF}$ and IVOMD coefficients had similar magnitude, suggesting that nutritive value of hulless barley straw can be presented using either CP, NDF or IVOMD. Increasing the nutritive value of barley straw by breeding requires efficient screening of large numbers of genotypes for straw quality. Neutral detergent fibers and $\mathrm{CP}$ are simpler to be determined compared to IVOMD. Thus, one of them could be used to express the nutritive value of the straw. Breeders can improve straw quality by targeting to increase $\mathrm{CP}$ and IVOMD or decrease NDF. Similar results were reported by Alkhtib et al. (2017) in lentil and Wamatu et al. (2017) in field pea. However, a simpler method is still required. It has been reported that botanical structure of faba bean straw can be used to screen genotypes for straw nutritive value (Alkhtib et al., 2016). Thus, studies on predicting the nutritive value of barley straw depending on botanical structure may be useful. The correlation between grain yield and straw traits was insignificant in both ETH and introduced landraces. Grain yield correlated moderately to straw yield but not to straw nutritive value parameters, indicating that improving nutritive value of ETH landraces and introduced landraces would not be associated with a decline in grain yield. Grain yield correlated positively to cell wall constituents and negatively to IVOMD. That implies that improving nutritive value of the straw should be done consciously. Weak correlations between food and feed traits were also reported in Ertiro et al. (2013) in maize, Blümmel et al. (2007) in pearl millet and Blümmel et al. (2010) in Sorghum. Cluster analysis indicated that 6 ETH landraces found in cluster 5 had superior grain yield and straw traits compared to other clusters, suggesting that selecting ETH landraces for food-feed traits holds promise.

Wide genetic variation in grain yield and straw traits in hulless barley implies high possibility to develop genotypes of hulless barley which combine superior grain yield and straw traits. ETH landraces could be a potential genetic pool for any effort to improve both grain yield and straw traits. However, variability in straw nutritive value should be confirmed for use by livestock. That could include botanical structure and physical traits of straw. The effect of the environment on performance of hulless barely genotypes in terms of food and feed traits should be determined. More studies are also needed to identify inheritance of straw traits. That will assist crop breeders to design appropriate approaches to develop dual purpose genotypes of hulless barley.

\section{Acknowledgement}

Authors gratefully acknowledge Holetta Agricultural Research, Debre Zeit Station for facilitating field activities and to the Animal Nutrition Laboratory of the International Livestock Research Institute (ILRI) in Addis Ababa, Ethiopia for analyses of straw samples. The financial support of the Council for at-Risk Academics is appreciated. The study was financially supported by the CGIAR Research Program on Livestock and Fish.

\section{Conflict of Interest}

The authors declare that they have no conflict of interest.

\section{References}

Alkhtib A, Wamatu J, Wegi T, Rischkowsky B (2016) Variation in the straw traits of morphological fractions of faba bean (Vicia faba L.) and implications for selecting for food-feed varieties. Animal Feed Science and Technology 222:122-131.

Alkhtib A, Wamatu J, Tolemariam E, Rischkowsky B (2017) Integrating straw yield and quality into multi-dimensional 
improvement of lentil (Lens culinaris). Journal of the Science of Food and Agriculture 97:4135-4141.

Association of Official Analytical Chemists International (2005) Official methods of analysis (18th edition). Gathersburg, MD.

Austin R, Bingham J, Blackwell D, Evans L, Ford M, Morgan C, Taylor M (1980) Genetic improvements in winter wheat yields since 1900 and associated physiological changes. Journal of Agricultural Science 94:675-689.

Blümmel M, Bidinger F, Hash T (2007) Management and cultivar effects on ruminant nutritional quality of pearl millet (Pennisetum glaucum (L.) R. Br.) stover: II. Effects of cultivar choice on stover quality and productivity. Field Crops Research 21:129-138.

Blümmel M, Khan A, Vadez V, Hash C, Rai K (2010) Variability in stover quality traits in commercial hybrids of pearl millet (Pennisetum glaucum) and grain-stover trait relationships. Animal Nutrition and Feed Technology 10S:29-38.

Capper B, Thomson E, Rihawi S, Termanini A, Macrae R (1986) The feeding value of straw from different genotypes of barley when given to Awassi sheep. Animal Production 42:337-342.

Capper B, Thomson E, Herbert F (1988) Genetic variation in the feeding value of barley and wheat straw. In: Reed J, Capper B, Neate P (Eds.) Plant Breeding and the Nutritive Value of Crop Residues, ILRI, Addis Ababa, Ethiopia.

Ceccarelli S, Grando S (1996) Importance of specific adaptation in breeding for marginal conditions. In: Strevica A, Paula L (Eds.) Proceeding of the First Barley Research Review Workshop, ICARDA/IAR, Addis Ababa, Ethiopia.

Central Statistical Agency (2016) Agricultural Sample Survey Report on: Area and Production of CropsStatistical Bulletin.Central Statistical Agency,Addis Ababa.

Cooper H, Spillane C, Hodgkin T (2001) Broadening the genetic base of crop production. CABI, Oxon

Ertiro B, Twumasi A, Blümmel M, Friesen D, Negera D, Abakemal D, Kitenge K (2013) Genetic variability of maize stover quality and the potential for genetic improvement of fodder value. Field Crops Research 153:79-85.

FAO (2016) FAOStatistical Database. Food and Agricultural Organization of the United Nations Rome Italy.

Federer W, Raghavarao D (1975) Augmented designs. Biometrics 31:29-35.

Goodchild A (1997) Effects of rainfall and temperature on the feeding value of barley straw in a semi-arid Mediterranean environment. Journal of Agricultural Science 129:353-366.
Grando S, Macpherson H (2005) Food barley: Importance, uses and local knowledge. ICARDA,Aleppo.

Heuzé V, Tran G, Nozière P, Bastianelli D (2016) Straws. Available on http://www.feedipedia.org/node/60, accessed on 23 March 2016.

Horrocks R, Vallentine J (1999) Harvested Forages. Academic Press, London.

Kaso T, Guben G (2015) Review of barley value chain management in Ethiopia. Journal of Biology and Agricultural Health 5:84-97.

Kearl L (1982) Nutrient requirements of ruminants in developing countries. International Feedstuffs Institute, Logan.

Kelley T, Rao P, Walker T (1991) The relative value of cereal straw fodder in the semi-arid tropics of India: Implications for cereal breeding programs at International Crops Research Institute for the Semi-Arid Tropics. In: Dvorak K (Ed.) Proceedings of a Conference Held at Rockefeller Foundation-International Institute of Tropical Agriculture, International Center of Tropical Agriculture, Ibadan, Nigeria.

Mamo B, Barber B, Steffenson B (2014) Genome-wide association mapping of zinc and iron concentration in barley landraces from Ethiopia and Eritrea. Journal of Cereal Science 3: 497-506.

Menke K, Steingass H (1988) Estimation of the energy feed value obtained from chemical analysis and in vitro gas production using rumen fluid. Animal Research and Development 28: 7-55.

Menke K, Raab L, Salewski A, Steingass H, Fritz D, Schneider W (1979) The estimation of the digestibility and metabolisable energy content of ruminant feeding stuffs from the gas production when they are incubated with rumen liquor. Journal of Agricultural Science 93: 217-222.

Riggs T, Hanson P, Start, Miles D (1981) Comparison of spring barley varieties grown in England and Wales between 1880 and 1980. Journal of Agricultural Science 97:599-610.

SAS (2012) SAS/STAT 12.1 User's Guide SAS Inc., Cary, NC, USA.

Mosisa W, Banziger M, Friesen D, Schulte G, Auf'm E, Diallo AO, Vivel B (2007) Protein quantity and quality, grain yield performance of quality protein maize and normal endosperm maize under different levels of nitrogen. African Crop Science Conference Proceedings. African Crop Science Society, El-Minia, Egypt. Volume 8: 1905-1999.

Schiere J, Joshi A, Seetharam A, Oosting S, Goodchild A, Deinum B, Van Keulen H (2004) Grain and straw for whole plant 
value: Implications for crop management and genetic improvement strategies. Experimental Agriculture 40:277-294.

Traxler G, Byerlee D (1993) A joint-product analysis of the adoption of modern cereal varieties in developing countries. American Journal of Agricultural Economics 75:981-989.

Van Soest P, Robertson J, Lewis B (1991) Methods of dietary fiber, neutral detergent fiber and non-starch polysaccharide in relation to animal nutrition. Journal of Dairy Science 74:3583-3597.

Wamatu J, Alemu T, Tolera T, Beyan M, Alkhtib A, Eshete M, Ahmed S, Rischkowsky B (2017) Selecting for food-feed traits in desi and kabuli genotypes of chickpea (Cicer arietinum). Journal of Experimental Biology and Agricultural Sciences 5: 852-860.

Zohary D, Hopf M (2000) Domestication of plants in the Old World, Oxford University Press, New York. 